\title{
EFEK RADIASI TERHADAP PERUBAHAN JUMLAH LEUKOSIT DAN ERITROSIT PADA PASIEN KANKER PAYUDARA SEBELUM DAN SETELAH RADIOTERAPI
}

\section{EFFECT OF RADIATION ON THE CHANGES NUMBER OF LEUKOCYTES AND ERYTHROCYTES IN BREAST CANCER PATIENTS BEFORE AND AFTER RADIOTHERAPY}

\author{
Agustina Dwi Prastanti ${ }^{1)}$, Sri Wahyuni ${ }^{2)}$, Siti Masrochah ${ }^{3)}$ \\ ${ }^{1,3)}$ Health Polytechnics of Semarang-Indonesia \\ ${ }^{2)}$ RSUP Dr. Kariadi, Semarang \\ e-mail : tina.atrodepkes17@gmail.com
}

\begin{abstract}
Background: Breast cancer is second cancer after a lung cancer as a cause of death from cancer in women. Breast cancer patients underwent radiotherapy using Co-60 with a total dose of $50 \mathrm{~Gy}$ and fractionated doses 2 Gy/day. Ionizing radiation takes a bad affect blood cells (leucocytes and erythrocytes). The purpose of this research to find out the changing in the number of leukocytes and erythrocytes in breast cancer patients who underwent radiotherapy.

Methods: The research uses the quantitative method with survey approach. Samples size in this research is 30 women who had breast cancer stage III. The independent variable of this research is radiotherapy treatment with Co-60, with 50 Gy total dose and fractionated dose about 2 Gy with 5 times in one week. The dependent variable in this research is the changing in the number of leucocytes and erythrocytes before irradiation, after 5 times irradiation and after 10 times irradiation. Data analyze used statistical with a comparative method to take a result.

Results: The results have found the average number of leucocytes in breast cancer patients before radiotherapy $\pm 6,41$ thousand/ $\mu \mathrm{L}$ after the irradiation 5 times decrease to $\pm 5,38$ thousand/ $\mu \mathrm{L}$ and after the irradiation, 10 times decrease to $\pm 4,50$ thousand/ $\mu \mathrm{L}$. The average number of erythrocytes in breast cancer patients before radiotherapy $\pm 4,50$ million $/ \mu \mathrm{L}$, after the irradiation 5 times decrease to $\pm 4,17$ million $/ \mu \mathrm{L}$ and after the irradiation 10 times to decrease to \pm 3.90 million $/ \mu \mathrm{L}$. Based on the statistical test, the results have found significant value $0,000<0.05$, then $\mathrm{Ha}$ is accepted. It means there are changes in the number of leucocytes and erythrocytes in breast cancer patients before and after radiotherapy.

Conclusion: Leukocyte levels change is a decline of 1:03 thousand / $\mathrm{mL}$ or at 16:07\%. Whereas after irradiation with 5 times to 10 times after irradiation decreased by 0.88 thousand / $\mathrm{mL}$ or $16: 36 \%$. Erythrocyte levels change is a decline of 0:33 million $/ \mathrm{mL}$ or at 7:33\%. Whereas after irradiation with 5 times to 10 times after irradiation decreased by 0:27 million / $\mathrm{mL}$ or 5:04\%
\end{abstract}

Keywords: radiation effects, leucocytes, erythrocytes, breast cancer, radiotherapy

\section{PENDAHULUAN}

World Health Organization (WHO) menyatakan bahwa lima besar kanker di dunia adalah kanker paru-paru, kanker payudara, kanker usus besar, kanker lambung dan kanker hati. Sementara data dari pemeriksaan patologi di Indonesia menyatakan bahwa urutan lima besar kanker adalah kanker leher rahim, kanker payudara, kelenjar getah bening, kulit dan kanker nasofaring (Anonim cit. Harianto, dkk 2005).

Perkembangan teknologi radioterapi berkembang dengan pesat, menuntut adanya kualitas pelayanan yang baik bagi masyarakat selaku pemakai jasa pelayanan kesehatan, khususnya di unit penunjang radiodiagnostik dan radioterapi. Untuk terapi atau penyembuhan kanker payudara dipergunakan radiasi sinar gamma, radiasi sinar gamma yang diberikan dapat membunuh sel-sel kanker juga memberikan pengaruh yang kurang baik terhadap haemopoitik pasien. Pasien dapat mengalami leukopeni yaitu berkurangnya jumlah leukosit dibawah $4000 / \mathrm{mm}^{3}$. Leukopeni dapat diakibatkan karena penyakit keganasan, radiasi sinar- $\mathrm{X}$ atau gamma dan status gizi yang buruk (Kartikasari, dkk, 2009).

Metode fraksinasi konvensional, pemberian radiasi dilakukan 5 kali dalam seminggu dengan dosis perfraksi berkisar antara 1,8 Gy dan 2 Gy dengan jumlah dosis pada umumnya 50-60 Gy. Pada jaringan normal metode ini berguna untuk memberi kesempatan perbaikan pada cedera subletal sifatnya diantara fraksi satu ke fraksi berikutnya (Susworo, 2007).

Prosedur tetap penyinaran radioterapi kanker payudara adalah menentukan stadium klinis, mencatat data riwayat penyakit dengan anamnesa, pemeriksaan laboratorium utama atau dasar termasuk dalam hal ini adalah pemeriksaan darah rutin berupa eritrosit, leukosit dan trombosit, pemeriksaan utama imaging diagnostik untuk diagnostik metastasis jauh, perencanaan teknis radiasi dengan Treatment Planning System (TPS), perencanaan dosis dan radioterapi palliatif (RSUP Dr. Sardjito, 2008). 
Berdasarkan Hukum Bergonie dan Tribondeou (1906), yang menyatakan bahwa "tingkat radiosensitivitas suatu sel atau jaringan berbanding lurus dengan kapasitas reproduksi dan berbanding terbalik dengan derajat diferensiasinya". Artinya semakin besar tingkat reproduksi (pembelahan) suatu sel atau jaringan semakin tinggi radiosensitivitasnya dan semakin besar derajat differensiasi suatu sel atau jaringan semakin kecil radiosensitivitasnya. Granulosit yang mempunyai umur rata-rata 24 jam dan 120 hari untuk eritrosit sehingga eritrosit mempunyai waktu yang cukup lama untuk pemulihan (Travis, 1984).

Sel leukosit dan eritrosit apabila terkena radiasi akan mengalami kematian. Jumlah normal sel leukosit dalam darah adalah 4-11 ribu/ $\mathrm{mm}^{3}$ Sedangkan jumlah normal sel eritrosit adalah $4,8 \mathrm{juta} / \mathrm{mm}^{3}$ pada wanita dan $5,4 \mathrm{juta} / \mathrm{mm}^{3}$ pada pria (Ganong, 2003). Sel leukosit yang didalamnya terdapat sel limfosit yang berfungsi sebagai pertahanan, apabila berkurang pertahanan tubuh terhadap penyakit menjadi lemah. Begitu pula dengan eritrosit, yang mempunyai fungsi utama mengangkut hemoglobin, dan seterusnya mengangkut oksigen dari paru-paru ke jaringan (Guyton dan Hall, 1997). Sehingga apabila eritrosit berkurang akan menghambat pengangkutan oksigen ke seluruh jaringan yang akan mengakibatkan makanan sel berkurang dan dapat mengalami anemia yaitu penyakit kekurangan sel darah merah (eritrosit).

Dari penelitian yang pernah dilakukan oleh Kartikasari, dkk pada pasien kanker serviks dengan menggunakan Co-60 menyebutkan bahwa terjadi penurunan kadar leukosit dari sebelum penyinaran sebesar $81.0 \%$, setelah 5 kali penyinaran turun menjadi $75.0 \%$ dan setelah 10 kali penyinaran turun kembali menjadi $72.5 \%$. Kadar Hemoglobin terjadi penurunan dari sebelum penyinaran sebesar $50.0 \%$, setelah 5 kali penyinaran menurun menjadi $46.4 \%$ dan setelah 10 kali penyinaran turun menjadi $35.3 \%$. Sedangkan kadar trombosit mengalami peningkatan sebelum penyinaran sebesar $76.2 \%$, setelah 5 kali penyinaran naik menjadi $79.8 \%$ dan setelah 10 kali penyinaran menjadi $82.4 \%$. Sedangkan belum ada penelitian yang mengkaji perubahan leukosit dan eritrosit pada kasus kanker payudara.

\section{METODE}

Penelitian Karya Tulis Ilmiah ini merupakan penelitian kuantitatif. Penelitian dilakukan dengan melakukan cek laboratorium darah pasien kanker payudara sebelum dilakukan penyinaran radioterapi, kemudian pasien kanker payudara dilakukan penyinaran radioterapi dengan menggunakan Co-60 yang mengeluarkan radiasi gamma kemudian dilakukan pengecekan laboratorium kembali terhadap sel darah pasien setelah dilakukan penyinaran 5 kali dan 10 kali.

Analisa data dilakukan dengan menggunakan SPSS apabila hasil uji tes normalitas tidak signifikan $(p>0.05)$ maka sebaran data normal dan dilanjutkan uji beda menggunakan paired T-test, sedangkan apabila hasil uji tes normalitas signifikan $(\mathrm{p}<0,05)$, maka sebaran data tidak normal dan dilakukan uji wilcoxon. Setelah dilakukan uji beda, apabila pada kolom sig (2 tailed) diperoleh nilai signifikansi 0,000 $(\mathrm{p}<0,05)$ maka Ha diterima, artinya ada perubahan yang signifikan jumlah leukosit dan eritrosit sebelum dan sesudah penyinaran radioterapi. Sedangkan apabila pada kolom sig (2 tailed) diperoleh nilai signifikansi p>0,05 maka Ho diterima, artinya tidak ada perubahan yang signifikan jumlah leukosit dan eritrosit sebelum dan sesudah penyinaran radioterapi. Kesimpulan dengan cara menetapkan Ha yang diterima atau Ho yang diterima berdasarkan hasil uji beda.

\section{HASIL}

Gambaran Perubahan Jumlah Leukosit pada Pasien Kanker Payudara Sebelum dan Setelah Penyinaran Radioterapi di laboratorium RSUP Dr. Sardjito Yogyakarta

Tebel 1. Perbedaan Penurunan Rata-rata Jumlah Leukosit dan Eritrosit pada Stadium IIIA

\begin{tabular}{ccccc}
\hline \multirow{2}{*}{ Uraian } & \multicolumn{4}{c}{ IIIA } \\
\cline { 2 - 5 } & Leu & Penurunan & Eri & Penurunan \\
\hline $\begin{array}{c}\text { Sebelum } \\
\text { Penyinaran }\end{array}$ & 6.18 & - & 4.61 & - \\
$\begin{array}{c}\text { Sesudah 5x } \\
\text { Penyinaran }\end{array}$ & 5.29 & 0.89 & 4.40 & 0.21 \\
$\begin{array}{c}\text { Sesudah 10x } \\
\text { Penyinaran }\end{array}$ & 4.47 & 0.82 & 4.23 & 0.17 \\
\hline
\end{tabular}

Tebel 2. Perbedaan Penurunan Rata-rata Jumlah Leukosit dan Eritrosit pada Stadium IIIB

\begin{tabular}{ccccc}
\hline \multirow{2}{*}{ Uraian } & \multicolumn{4}{c}{ IIIB } \\
\cline { 2 - 5 } & Leu & Penurunan & Eri & Penurunan \\
\hline Sebelum & 6.71 & - & 4.42 & - \\
Penyinaran & & & & \\
Sesudah 5x & 5.58 & 1.13 & 4.14 & 0.28 \\
$\begin{array}{c}\text { Penyinaran } \\
\text { Sesudah 10x } \\
\text { Penyinaran }\end{array}$ & 4.75 & 0.83 & 3.93 & 0.21 \\
\hline
\end{tabular}

Berdasarkan perbedaan penurunan rata-rata jumlah leukosit dan eritrosit pada stadium IIIA dan IIIB (tabel 1), terlihat penurunan rata-rata jumlah leukosit dan eritrosit pada stadium IIIB lebih besar daripada stadium IIIA.

Tabel 3. Karakteristik kadar leukosit pada pasien kanker payudara sebelum dan setelah penyinaran

\begin{tabular}{cccccc}
\hline Uraian & $\mathrm{N}$ & $\begin{array}{c}\text { Mean } \\
(\mathrm{ribu} / \mu \mathrm{L})\end{array}$ & $\mathrm{SD}$ & $\begin{array}{c}\mathrm{Mi} \\
\mathrm{n}\end{array}$ & $\mathrm{Max}$ \\
\hline $\begin{array}{c}\text { Sebelum } \\
\text { penyinaran }\end{array}$ & 30 & \pm 6.41 & $\begin{array}{c}1.3 \\
9\end{array}$ & $\begin{array}{c}4.8 \\
0\end{array}$ & 10.54 \\
$\begin{array}{c}\text { Setelah 5 kali } \\
\text { penyinaran }\end{array}$ & 30 & \pm 5.38 & $\begin{array}{c}1.4 \\
1\end{array}$ & $\begin{array}{c}3.7 \\
8\end{array}$ & 9.97 \\
$\begin{array}{c}\text { Setelah 10 kali } \\
\text { penyinaran }\end{array}$ & 30 & \pm 4.50 & $\begin{array}{c}1.3 \\
1\end{array}$ & $\begin{array}{c}3.0 \\
8\end{array}$ & 9.30 \\
\hline
\end{tabular}

Berdasarkan tabel rata-rata kadar leukosit responden sebelum dan setelah penyinaran didapatkan hasil rata-rata sebelum penyinaran sebesar $\pm 6.41 \mathrm{ribu} / \mu \mathrm{L}$, setelah dilakukan 5 kali penyinaran menurun menjadi $\pm 5.38 \mathrm{ribu} / \mu \mathrm{L}$ dan setelah dilakukan 10 kali penyinaran turun kembali sebesar \pm 4.50 $\mathrm{ribu} / \mu \mathrm{L}$

Setelah diberi penyinaran menggunakan Co-60 yang mengeluarkan sinar gamma sebanyak 5 kali, kadar leukosit 
tertinggi dari 30 responden adalah $9.97 \mathrm{ribu} / \mu \mathrm{L}$ sedangkan kadar leukosit terendah adalah $3.78 \mathrm{ribu} / \mu \mathrm{L}$.

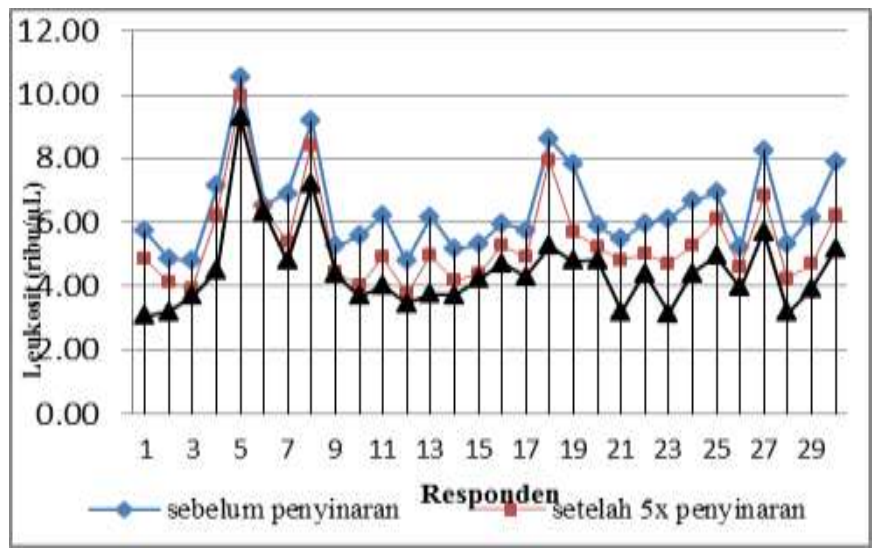

Gambar 1. Grafik Jumlah Kadar Leukosit Pasien Kanker Payudara Sebelum dan setelah Radioterapi

Setelah dilakukan 10 kali penyinaran kadar leukosit tertinggi pada responden menjadi 9.30 ribu/ $\mu \mathrm{L}$ dan kadar leukosit terendah menjadi $3.08 \mathrm{ribu} / \mu \mathrm{L}$.

Tabel 4. Distribusi Responden dengan Perubahan Leukosit Sebelum dan Setelah Radioterapi

\begin{tabular}{|c|c|c|c|c|c|c|}
\hline \multirow[t]{2}{*}{$\begin{array}{c}\text { Kadar } \\
\text { Leukosit } \\
(\text { ribu/ } / \mu \mathrm{L})\end{array}$} & \multicolumn{2}{|c|}{$\begin{array}{c}\text { Sebelum } \\
\text { penyinara } \\
\mathrm{n}\end{array}$} & \multicolumn{2}{|c|}{$\begin{array}{c}\text { Setelah } 5 \mathrm{x} \\
\text { penyinara } \\
\mathrm{n}\end{array}$} & \multicolumn{2}{|c|}{$\begin{array}{c}\text { Setelah } \\
10 x \\
\text { penyinara } \\
n\end{array}$} \\
\hline & $\mathrm{N}$ & $\%$ & $\mathrm{~N}$ & $\%$ & $\mathrm{~N}$ & $\%$ \\
\hline $\begin{array}{l}<4 \text { (tidak } \\
\text { normal) }\end{array}$ & 0 & 0 & 2 & 6.67 & $\begin{array}{l}1 \\
2\end{array}$ & 40 \\
\hline 4-11 (normal) & 30 & 100 & 28 & $\begin{array}{c}93.3 \\
3\end{array}$ & $\begin{array}{l}1 \\
8\end{array}$ & 60 \\
\hline $\begin{array}{c}>11 \text { (tidak } \\
\text { normal) }\end{array}$ & 0 & 0 & 0 & 0 & 0 & 0 \\
\hline Jumlah & 30 & 100 & 30 & 100 & $\begin{array}{l}3 \\
0\end{array}$ & 100 \\
\hline
\end{tabular}

Gambaran Perubahan Jumlah Eritrosit pada Pasien Kanker Payudara Sebelum dan Setelah Penyinaran Radioterapi

Tabel 5. Karakteristik kadar eritrosit pada pasien kanker payudara sebelum dan setelah penyinaran

\begin{tabular}{cccccc}
\multicolumn{5}{c}{ sebelum dan setelah penyinaran } \\
\hline Uraian & $\mathrm{N}$ & $\begin{array}{c}\text { Mean } \\
\text { (juta/ } \mu \mathrm{L})\end{array}$ & $\mathrm{SD}$ & Min & Max \\
\hline $\begin{array}{c}\text { Sebelum } \\
\text { penyinaran }\end{array}$ & 30 & \pm 4.50 & 0.35 & 3.97 & 5.59 \\
$\begin{array}{c}\text { Setelah 5x } \\
\text { penyinaran }\end{array}$ & 30 & \pm 4.17 & 0.44 & 3.07 & 4.81 \\
$\begin{array}{c}\text { Setelah 10x } \\
\text { penyinaran }\end{array}$ & 30 & \pm 3.90 & 0.55 & 2.37 & 4.64
\end{tabular}

Berdasarkan tabel rata-rata kadar eritrosit responden sebelum dan setelah penyinaran didapatkan hasil rata-rata sebelum penyinaran sebesar $\pm 4.50 \mathrm{juta} / \mu \mathrm{L}$, setelah dilakukan 5 kali penyinaran menurun menjadi \pm 4.17 juta/ $\mu \mathrm{L}$ dan setelah dilakukan 10 kali penyinaran turun kembali sebesar \pm 3.90 juta/ $\mu \mathrm{L}$. mengalami penurunan kembali sebesar $13.33 \%$ dari semula atau 0.60 juta/ $\mu \mathrm{L}$ dari rata-rata sebelum penyinaran.

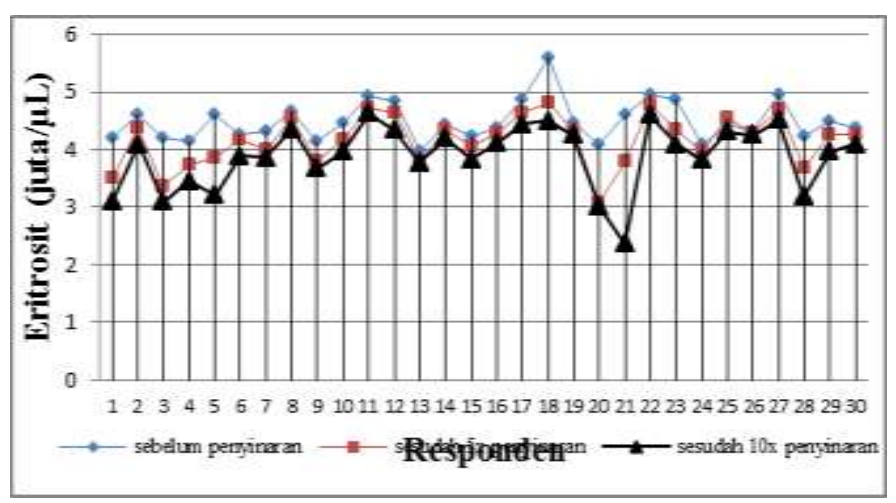

Gambar 2. Grafik Jumlah Kadar Eritrosit pada Pasien Kanker Payudara Sebelum dan Setelah Radioterapi

Hasil laboratorium kadar leukosit pada pasien kanker payudara sebelum penyinaran dari 30 responden didapat kadar eritrosit tertinggi $5.59 \mathrm{juta} / \mu \mathrm{L}$ sedangakan kadar eritrosit terendah yaitu $3.97 \mathrm{juta} / \mu \mathrm{L}$.

Setelah diberi penyinaran menggunakan Co-60 dengan pancaran radiasi gamma sebanyak 5 kali, kadar eritrosit tertinggi dari 30 responden adalah $4.81 \mathrm{juta} / \mu \mathrm{L}$ sedangkan kadar eritrosit terendah adalah $3.07 \mathrm{juta} / \mu \mathrm{L}$.

Setelah dilakukan 10 kali penyinaran kadar eritrosit tertinggi pada responden menjadi 4.64 juta/ $\mu \mathrm{L}$ dan kadar eritrosit terendah menjadi $2.37 \mathrm{juta} / \mu \mathrm{L}$.

Tabel 6. Distribusi Responden dengan Perubahan Eritrosit Sebelum

\begin{tabular}{|c|c|c|c|c|c|c|}
\hline \multirow{2}{*}{$\begin{array}{c}\text { Kadar } \\
\text { eritrosit } \\
(\mathrm{juta} / \mu \mathrm{L})\end{array}$} & \multicolumn{2}{|c|}{$\begin{array}{c}\text { Sebelum } \\
\text { penyinaran }\end{array}$} & \multicolumn{2}{|c|}{$\begin{array}{c}\text { Setelah 5 } \\
\text { kali } \\
\text { penyinaran }\end{array}$} & \multicolumn{2}{|c|}{$\begin{array}{c}\text { Setelah } 10 \\
\text { kali } \\
\text { penyinaran }\end{array}$} \\
\hline & $\mathrm{N}$ & $\%$ & $\mathrm{~N}$ & $\%$ & $\mathrm{~N}$ & $\%$ \\
\hline $\begin{array}{l}<4 \text { (tidak } \\
\text { normal) }\end{array}$ & 1 & $\begin{array}{c}3.3 \\
3\end{array}$ & 10 & 33.33 & 15 & 50 \\
\hline 4-5 (normal) & 28 & $\begin{array}{l}93 . \\
33\end{array}$ & 20 & 66.67 & 15 & 50 \\
\hline $\begin{array}{l}>5 \text { (tidak } \\
\text { normal) }\end{array}$ & 1 & $\begin{array}{c}3.3 \\
3\end{array}$ & 0 & 0 & 0 & 0 \\
\hline Jumlah & 30 & 100 & 30 & 100 & 30 & 100 \\
\hline
\end{tabular}

Berdasarkan persentase kadar eritrosit (sel darah merah) dalam darah sebelum penyinaran dari 30 responden, sebelum penyinaran terdapat $93.33 \%$ responden mempunyai kadar eritrosit normal (3.33\% yang di bawah kadar eritrosit normal dan $3.33 \%$ di atas kadar eritrosit normal). Setelah dilakukan 5 kali penyinaran menggunakan Co-60 yang mengeluarkan radiasi gamma maka terdapat angka penurunan pada responden yang memiliki memiliki kadar eritrosit normal dari $93.33 \%$ dari responden menjadi $66.67 \%$ dari responden 
sedangkan yang memiliki kadar eritrosit tidak normal meningkat menjadi $33.33 \%$ dari total responden.

Setelah dilakukan 10 kali penyinaran maka kadar eritrosit normal pada responden berkurang kembali dari $66.67 \%$ dari responden menjadi $50 \%$ dari responden sedangkan yang memiliki kadar leukosit tidak normal semakin meningkat dari $33.33 \%$ menjadi $50 \%$ dari total responden.

Uji Beda Hasil Laboratorium Kadar Leukosit pada Pasien Kanker Payudara Sebelum dan Setelah 5 Kali Penyinaran Radioterapi pada Responden

Hasil laboratorium kadar leukosit sebelum dilakukan penyinaran radioterapi menggunakan radiasi gamma yang berasal dari Co-60 dilakukan uji beda dengan kadar leukosit setelah dilakukan penyinaran sebanyak 5 kali penyinaran. Berdasarkan hasil uji normalitas data dengan menggunakan kolmogorov-smirnov diperoleh nilai signifikasi (0.011 dan 0.003) yang berarti $\mathrm{P}<0.05$ maka sebaran data tidak normal kemudian dilakukan uji beda menggunakan wilcoxon.

Berdasarkan hasil uji beda menggunakan wilcoxon, pada kolom Asymp. Sig. (2-tailed) diperoleh nilai signifikansi 0.000 yang berarti $\mathrm{P}<0.05$, maka Ha diterima, artinya ada perubahan yang signifikansi jumlah leukosit sebelum dan setelah 5 kali penyinaran radioterapi.

Uji Beda Hasil Laboratorium Kadar Leukosit pada Pasien Kanker Payudara Sebelum dan Setelah 10 Kali Penyinaran Radioterapi Pada Responden

Hasil laboratorium kadar leukosit sebelum dilakukan penyinaran radioterapi menggunakan radiasi gamma yang berasal dari Co-60 dilakukan uji beda dengan kadar leukosit setelah dilakukan penyinaran sebanyak 10 kali penyinaran. Berdasarkan hasil uji normalitas data dengan menggunakan kolmogorov-smirnov diperoleh nilai signifikasi 0.011 dan 0.020) yang berarti $\mathrm{P}<0.05$ maka sebaran data tidak normal kemudian dilakukan uji beda menggunakan wilcoxon.

Berdasarkan hasil uji beda menggunakan wilcoxon, pada kolom Asymp. Sig (2-Tailed) diperoleh nilai signifikansi 0.000 yang berarti $\mathrm{P}<0.05$, maka Ha diterima, artinya ada perubahan yang signifikansi jumlah leukosit sebelum dan setelah 10 kali penyinaran radioterapi.

Jumlah Penurunan Leukosit pada Pasien Kanker Payudara Sebelum dan Sesudah Penyinaran Radioterapi

Tabel 7. Penurunan Kadar Leukosit pada Pasien Kanker Payudara Sebelum dan Sesudah Penyinaran

\begin{tabular}{|c|c|c|c|}
\hline Uraian & $\begin{array}{c}\text { Mean } \\
(\text { ribu/ } / \mu \mathrm{L})\end{array}$ & Penurunan & Persentase \\
\hline $\begin{array}{c}\text { Sebelum } \\
\text { penyinaran }\end{array}$ & \pm 6.41 & - & - \\
\hline $\begin{array}{l}\text { Setelah } 5 x \\
\text { penyinaran }\end{array}$ & \pm 5.38 & 1.03 & $16.07 \%$ \\
\hline $\begin{array}{l}\text { Setelah } 10 \mathrm{x} \\
\text { penyinaran }\end{array}$ & \pm 4.50 & 0.88 & $16.36 \%$ \\
\hline
\end{tabular}

Uji Beda Hasil Laboratorium Kadar Eritrosit pada Pasien Kanker Payudara Sebelum dan Setelah 5 Kali Penyinaran Radioterapi Pada Responden

Hasil laboratorium kadar eritrosit sebelum dilakukan penyinaran radioterapi menggunakan radiasi gamma yang berasal dari Co-60 dilakukan uji beda dengan kadar leukosit setelah dilakukan penyinaran sebanyak 5 kali penyinaran. Berdasarkan hasil uji normalitas data dengan menggunakan kolmogorov-smirnov diperoleh nilai signifikasi (0.200 dan 0.200) yang berarti $\mathrm{P}>0.05$ maka sebaran data normal kemudian dilakukan uji beda menggunakan paired T-test.

Berdasarkan hasil uji beda menggunakan paired T-test, pada kolom Sig. (2-tailed) diperoleh nilai signifikansi 0.000 yang berarti $\mathrm{P}<0.05$, maka Ha diterima, artinya ada perubahan yang signifikansi jumlah eritrosit sebelum dan setelah 5 kali penyinaran radioterapi.

Uji Beda Hasil Laboratorium Kadar Eritrosit pada Pasien Kanker Payudara Sebelum dan Setelah 10 Kali Penyinaran Radioterapi Pada Responden

Hasil laboratorium kadar eritrosit sebelum dilakukan penyinaran radioterapi menggunakan radiasi gamma yang berasal dari Co-60 dilakukan uji beda dengan kadar leukosit setelah dilakukan penyinaran sebanyak 10 kali penyinaran. Berdasarkan hasil uji normalitas data dengan menggunakan kolmogorov-smirnov diperoleh nilai signifikasi (0.200 dan 0.129) yang berarti $\mathrm{P}>0.05$ maka sebaran data normal kemudian dilakukan uji beda menggunakan paired T-test.

Berdasarkan hasil uji beda menggunakan paired T-test, pada kolom Sig. (2-tailed) diperoleh nilai signifikansi 0.000 yang berarti $\mathrm{P}<0.05$, maka Ha diterima, artinya ada perubahan yang signifikansi jumlah leukosit sebelum dan setelah 5 kali penyinaran radioterapi.

Jumlah Penurunan Eritrosit pada Pasien Kanker Payudara Sebelum dan Sesudah Penyinaran Radioterapi

Tabel 8. Penurunan Kadar Eritrosit pada Pasien Kanker Payudara Sebelum dan Sesudah Penyinaran

\begin{tabular}{cccc}
\hline Uraian & $\begin{array}{c}\text { Mean } \\
\text { (juta/ } \mu \mathrm{L})\end{array}$ & $\begin{array}{c}\text { Selisi } \\
\mathrm{h}\end{array}$ & Persentase \\
\hline $\begin{array}{c}\text { Sebelum } \\
\text { penyinaran }\end{array}$ & \pm 4.50 & - & - \\
$\begin{array}{c}\text { Setelah 5 kali } \\
\text { penyinaran }\end{array}$ & \pm 4.17 & 0.33 & $7.33 \%$ \\
$\begin{array}{c}\text { Setelah 10 kali } \\
\text { penyinaran }\end{array}$ & \pm 3.90 & 0.27 & $5.04 \%$ \\
\hline
\end{tabular}

Berdasarkan tabel tersebut, penurunan kadar eritrosit sebelum penyinaran dengan setelah dilakukan 5 kali penyinaran sebesar 0.33 juta/ $\mu \mathrm{L}$ atau sebesar $7.33 \%$ dari kadar eritrisot mula-mula lebih besar daripada penurunan kadar leukosit setelah dilakukan 5 kali penyinaran dengan setelah dilakukan 10 kali penyinaran yaitu sebesar 0.27 juta/ $\mu \mathrm{L}$ atau $5.04 \%$ dari kadar eritrosit mula-mula.

\section{DISKUSI}

Dalam penelitian ini, peneliti hanya menggunakan sumber radiasi dari Co-60 dengan pancaran radiasi gamma yang diarahkan langsung ke pasien. Radiasi yang dipancarkan tersebut berfungsi untuk membunuh sel-sel kanker pada tubuh pasien dengan sedapat mungkin meminimalkan kerusakan pada jaringan normal di sekitar dan yang dilaluinya.

Jika dilihat dari data responden menurut kelompok umur, responden terbanyak pada usia 41-45 tahun sebanyak $30 \%$ 
dari 30 responden. Sedangkan dilihat dari penggolongan stadium, stadium terbanyak yaitu stadium IIIB sebanyak 63.33 $\%$.

Berdasarkan hasil penelitian tersebut, menurut peneliti terjadi penurunan kadar leukosit pada pasien kanker payudara sebelum dilakukan radioterapi dan sesudah dilakukan radioterapi. Hal ini sesuai dengan teori. Menurut Travis, 1984, dosis serendah 10 rad, sudah dapat menurunkan jumlah limfosit. Limfosit merupakan bagian dari leukosit (sel darah putih). Sel darah putih terdiri dari netrofil, eosinofi, basofil, monosit dan limfosit (Guyton, 1997).

Apabila dosis $10 \mathrm{rad}(1 \mathrm{rad}=0,01$ Gray) sudah dapat menurunkan jumlah leukosit, maka selama 5 kali penyinaran akumulasi dosis yang didapat pasien kanker payudara sebesar $10 \mathrm{~Gy}(1000 \mathrm{rad})$ dan setelah 10 kali penyinaran pasien kanker payudara mendapat akumulasi dosis sebesar 20 Gy (2000 rad) sehingga kadar leukosit dalam darah pasien kanker payudara yang menjalani radioterapi akan sangat menurun.

Penurunan tersebut dapat terlihat dari kondisi umum pasien yang terlihat lemah, berat badan menurun, nafsu makan berkurang. Agar tetap dapat menjalankan penyinaran radioterapi pasien kanker payudara harus mengkonsumsi makanan yang bergizi. Konsumsi pangan yang bergizi dapat mendukung proses pembentukan sel darah.

Berdasarkan hasil penelitian tersebut, menurut peneliti terjadi penurunan kadar eritrosit pada pasien kanker payudara sebelum dilakukan radioterapi dan sesudah dilakukan radioterapi. Hal ini sesuai dengan teori. Menurut Travis, 1984, eritrosit dapat berkurang apabila terkena dosis sebesar $50 \mathrm{rad}$.

Apabila dosis $50 \mathrm{rad}(1 \mathrm{rad}=0,01$ Gray) sudah dapat menurunkan jumlah eritrosit, maka selama 5 kali penyinaran akumulasi dosis yang didapat pasien kanker payudara sebesar 10 Gy (1000 rad) dan setelah 10 kali penyinaran pasien kanker payudara mendapat akumulasi dosis sebesar $20 \mathrm{~Gy}(2000 \mathrm{rad})$ yaitu lebih besar dari 50 rad sehingga kadar eritrosit dalam darah pasien kanker payudara yang menjalani radioterapi akan sangat menurun tetapi penurunannya tidak sebesar leukosit karena radiosensitivitas leukosit lebih tinggi daripada radiosensitivitas eritrosit sehingga leukosit dengan dosis 10 rad sudah dapat menurun. Urutan tingkat radiosensitivitas sel dari radiosensitif tinggi ke rendah (Seibert, 1996 cit. Alan Jackson, 2001) adalah sebagai berikut : limfosit (bagian dari leukosit), eritroblast, granulosit, sel epitel, sel endotelia, sel jaringan ikat, sel tulang, dan sel saraf.

Pada penyinaran radioterapi kanker payudara tampak jelas menurunkan sel darah putih. Hal ini karena sel darah putih memiliki sensitivitas terbesar karena termasuk sel immatur yang memiliki tingkat reproduksi tinggi. Sesuai hukum Bergonie dan Tribondeou (1906), yang menyatakan bahwa " tingkat radiosensitivitas suatu sel atau jaringan berbanding lurus dengan kapasitas reproduksi dan berbanding terbalik dengan derajat diferensiasinya". Pada penelitian ini semakin banyak penyinaran yang diberikan, dosis total radiasi yang mengenai sumsum tulang semakin tinggi, meskipun dilakukan dengan fraksinasi dimungkinkan perbaikan sel, tetapi dosis total yang diterima secara akumulasi lebih banyak sehingga mengakibatkan penurunan jumlah leukosit. Jadi semakin banyak akumulasi dosis total juga semakin menurunkan jumlah leukosit. Oleh karena itu, dalam radioterapi setiap lima kali penyinaran dilakukan perlu pengecekan terhadap kadar darah pasien untuk mengetahui respon biologi terhadap sel. Apabila kondisi pasien drop, atau jumlah sel darah dibawah normal maka pasien perlu istirahat dari penyinaran atau diberi stimulan untuk meningkatkan leukosit agar tetap dapat melakukan penyinaran.

Penurunan kadar eritrosit lebih kecil daripada penurunan kadar leukosit. Adanya penurunan kadar leukosit lebih besar dari penurunan kadar eritrosit karena leukosit (sel darah putih) merupakan komponen darah yang paling sensitif terhadap radiasi (Travis, 1984; Siebert, 1996; Sherer, 2006). Penelitian ini hanya dapat diamati hingga penyinaran ke-10, karena setiap sampel tidak selalu rutin dilakukan pemeriksaan darah hinggga penyinaran ke-15 sampai ke-25 kali.

\section{SIMPULAN}

Berdasarkan hasil uji beda, Ha diterima yaitu ada perubahan jumlah leukosit dan eritrosit pada pasien kanker payudara sebelum dan setelah radioterapi. Kadar leukosit mengalami perubahan yaitu terjadi penurunan sebesar 1.03 ribu/ $\mu \mathrm{L}$ atau sebesar $16.07 \%$. Sedangkan setelah dilakukan 5 kali penyinaran dengan setelah dilakukan 10 kali penyinaran menurun sebesar $0.88 \mathrm{ribu} / \mu \mathrm{L}$ atau $16.36 \%$. Kadar eritrosit mengalami perubahan yaitu terjadi penurunan sebesar 0.33 juta/ $\mu \mathrm{L}$ atau sebesar $7.33 \%$. Sedangkan setelah dilakukan 5 kali penyinaran dengan setelah dilakukan 10 kali penyinaran menurun sebesar $0.27 \mathrm{juta} / \mu \mathrm{L}$ atau $5.04 \%$.

\section{DAFTAR PUSTAKA}

Akhadi, M. 1997. Dasar-Dasar Proteksi Radioterapi. Jakarta : Rineka Cipta.

Desantis, C; Siegel R. Jemal A. 2011. Breast Cancer Facts \& Figures 2011 2012. Atlanta-Georgia : American Cancer Society, Inc.

Ganong, W. F. 2003. Review of Medical Physiology 20th. Alih bahasa Djauhari, dkk. Jakarta: EGC

Guyton, A.C. \& Hall, J.E. 1997. Textbook of Medical Physiology 9th. Alih bahasa Irawati, dkk. Jakarta : EGC.

Harianto, Rina M, Hery S. 2005. Risiko Penggunaan Pil Kontrasepsi Kombinasi terhadap kejadian Kanker Payudara pada Reseptor KB di Perjan RS Dr. Cipto Mangunkusumo. Vol II. Jakarta : Majalah Ilmu Kefarmasian.

Kartikasari, Yeti; Siti M, Rini I. 2009. Perubahan haemopoitik pada Pasien Ca Serviks dengan Penyinaran Radioterapi. Semarang : Politeknik Kesehatan KEMENKES Semarang.

Price, S.A. dan Wilson, L.M. 2006. Pathophysiology: Clinical Concepts of Disease Processes 6th. Alih bahasa Pendit, dkk. Jakarta : EGC.

Rasad, S. 2009. Radiologi Diagnostik. Edisi 2. Jakarta : Balai Penerbit FKUI.

RSUP. Dr. Sardjito. 2008. Kumpulan Protap Radioterapi RSUP Dr. Sardjito. Yogyakarta: Instalasi Radiologi RSUP Dr. Sardjito Yogyakarta.

Sherer, M.A., Visconti P.A., Ritenour E.R. 2006. Radiation Protection 5th. St Louis : Mosby, Inc.

Soetrisno, E. 2010. Buku Ajar Patologi II (khusus) Payudara, Edisi 1. Jakarta Sagung Seto.

Susworo, R. 2007. Radioterapi. Dasar-Dasar Radioterapi. Tata Laksana radioterapi Penyakit Kanker. Jakarta : Universitas Indonesia.

Tierney, M. L. 2004. Current Medical Diagnosis \& Treatment. 43th Edition. New York : Lange Medical Books. 